\title{
Primary renal teratoma: a rare entity
}

\author{
Karima Idrissi-Serhrouchni ${ }^{1}$, Hinde El-Fatemi ${ }^{1}$, Aziz El madi ${ }^{2}$, Khadija Benhayoun $^{1}$, Laila Chbani ${ }^{1}$, \\ Taoufik Harmouch', Youssef Bouabdellah ${ }^{2}$ and Afaf Amarti ${ }^{1}$
}

\begin{abstract}
Teratomas are neoplasms that arise from pluripotent cells and can differentiate along one or more embryonic germ lines. Renal teratoma is an exceedingly rare condition. Teratomas commonly arise in the gonads, sacrococcygeal region, pineal gland, and retroperitoneum. They present mainly as an abdominal mass with few other symptoms. Majority of the tumors are benign, situated on the left side and para renal, occasional lesions are bilateral. If diagnosed early, they are amenable to curative excision.

Renal teratomas are rare and most have been dismissed as cases of teratoid nephroblastomas or retroperitoneal teratomas secondarily invading the kidney. The differentiation between these two neoplasms in the kidney is often problematic.

We present a case of intrarenal immature teratoma in a six-month-old baby girl.

Virtual slides: The virtual slides for this article can be found here: http://www.diagnosticpathology.diagnomx.eu/ vs/1746249869599954.
\end{abstract}

Keywords: Teratoma, Immature, Wilms, Kidney, Extragonadal

\section{Background}

Teratomas are neoplasms that arise from pluripotent cells and can differentiate along one or more embryonic germ lines [1]. Renal teratoma is an exceedingly rare condition [1]. Teratomas commonly arise in the gonads, sacrococcygeal region, pineal gland, and retroperitoneum. The proximity of the genital ridge to the nephrogenic anlage may partly explain how germ cells could be displaced within the kidney [2].

To the best of our knowledge, our patient is the second known case with an immature teratoma arising from ectopic kidney the first one was developed in a horseshoe kidney.

We present a case of intrarenal immature teratoma in a six-month-old baby girl and discuss the pathology of this rare entity.

\section{Case report}

A six-month-old baby girl was admitted in the department of paediatric surgery of Hassan II university hospital in Morocco, with the complaints of abdominal distension and pain since one month. On examination her weight was $5.5 \mathrm{kgs}$ and her abdomen was hugely distended. On

\footnotetext{
* Correspondence: idrissisehrouchni@yahoo.fr

'Department of Pathology, Hassan II University Hospital, Fez 30000, Morocco Full list of author information is available at the end of the article
}

palpation, a firm mass occupying all of the left lumb of the abdomen was palpable, which was tender, moving with respiration and the margins were irregular. Both the renal and liver functions as well as the findings of hematological studies were within the normal limits. A chest $\mathrm{x}$-ray showed no abnormality. Abdominal ultrasonography demonstrated a pelvic left kidney measuring $18 \mathrm{cms}$ in diameter with an important expansion of the excretory cavities and internal cystic and solid changes. Computed tomography showed a mass containing low-density areas of the left kidney. The right kidney was normal. The patient did not found any more tumors in the other organs. Because the most frequent tumor of the kidney occurring in newborns is congenital mesoblastic nephroma and patients with ectopic kidneys have a high risk for Wilms' tumor, a diagnosis of either mesoblastic nephroma or Wilms' tumor arising from ectopic kidney was tentatively made, and she was thus considered to be indicated for surgery.

Patient was operated upon; laparotomy was done through a median underumblical incision. A large partly cystic and partly solid mass with extensive areas of haemorrhage in the cystic areas was present in the left pelvic region. It was roughly spherical in shape. Postoperative recovery of the patient was uneventful and she was discharged on 10th postoperative day. The specimen was sent for histopathological examination.
C Biomed Central

(c) 2013 Idrissi-Serhrouchni et al.; licensee BioMed Central Ltd. This is an Open Access article distributed under the terms of the Creative Commons Attribution License (http://creativecommons.org/licenses/by/2.0), which permits unrestricted use,

distribution, and reproduction in any medium, provided the original work is properly cited. 
Grossly a large mass was received measuring $18 \times 12 \times 8$ $\mathrm{cms}$ in maximum dimensions. It weighed $200 \mathrm{Gms}$, linked to an ureter of $3 \times 0,2 \mathrm{cms}$. On sectioning a multilocular circumscribed lesion was identified measuring 2,5 at 10 cms. It was attached to the cystic wall, which focally showed thickened brownish areas in the wall (Figure 1). The entire kidney was replaced by the lesion, only a thin rim of renal parenchyma was identified at the periphery. Multiple sections were taken from the cyst wall and from the nodular lesion and vessels.

Microscopically small cystic spaces lined by keratinizing stratified squamous epithelium with skin adnexae were identified (Figure 2). The solid areas showed large foci of cartilage, mucinous columnar epithelium (Figure 3) and bone formation (Figure 4). Melanin containing cells and neuroglial cells with occasional foci of immature neuroectodermal tissue were also identified (Figures 5 and 6). The cyst wall was thick fibromuscular without any lining. Sections from solid areas in the cyst wall revealed immature renal tissue. The diagnosis of immature teratoma was retained.

\section{Discussion}

Teratomas are rare neoplasms (incidence 0.7/100.000 children/year) with tissue derivatives of all three germ layers [3]. Teratomas mostly occur in the ovaries, the sacrococcygeal region, the testes, the central nerval system, the mediastinum, and only rarely in other locations with less than $5 \%$ occurring in the abdomen [2,3]. Kidney is one of the least common locations for teratomas and other germ cell tumors [1]. Teratomas are thought to have been present since birth, or even before birth, and are therefore considered as congenital tumors [3]. Retroperitoneal teratomas exhibit a bimodal presentation, with peaks in the first six months of life and early

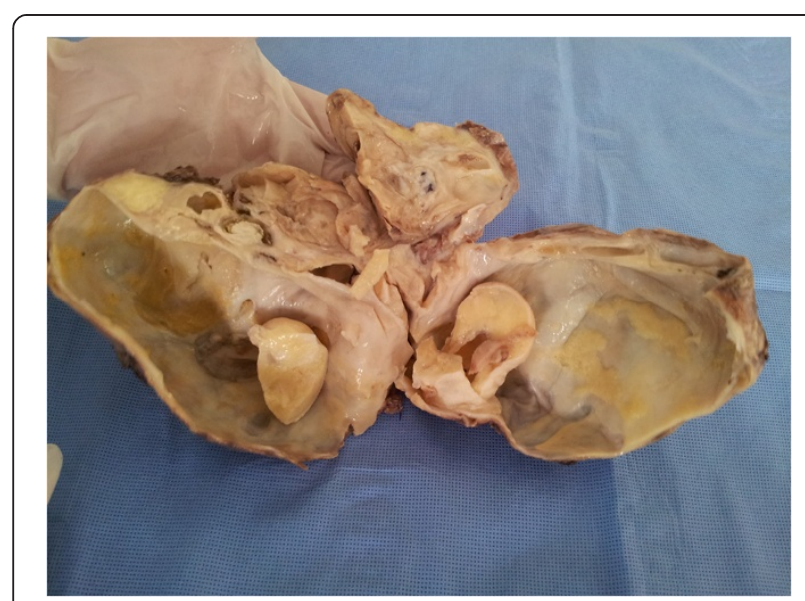

Figure 1 Gross view of lesion shows an encapsulated tumor $(18 \mathrm{~cm})$ with a yellowish tan cut surface. The interior was cystic with solid structures.

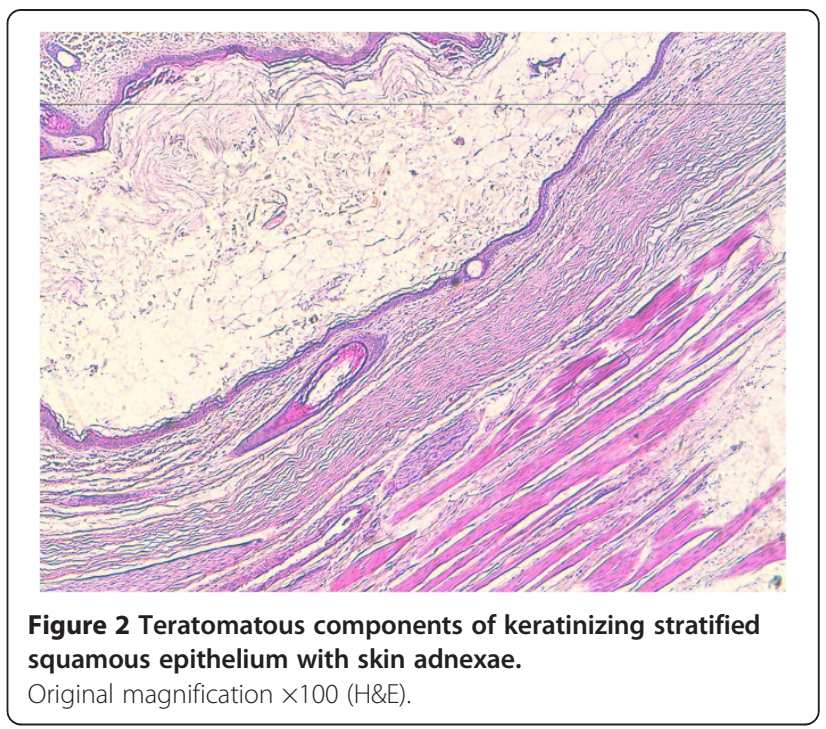

adulthood [2]. Literature does not reveal a side or gender predilection and almost equal incidence in males and females have been reported [4]. The first reported case of teratoma of kidney was in 1934, when Mc Curdy described this entity in a seven-week-old child with Prune-Belly syndrome [5]. Since, fifteen prior case reports were found in a MEDLINE search and we additioned our case to this data, the main findings for these cases are summarized in Table 1 [6-20].

The clinical symptoms are an abdominal mass, abdominal pain, abdominal discomfort, pyelonephritis, and constipation [18]. Occasionally, the tumor is present antenatally and diagnosed at birth, these neonatal teratomas have a higher incidence of malignancy than those in older children $[4,21]$. The diagnostic algorithm was palpation of a solid flank mass, in our case it was a pelvic

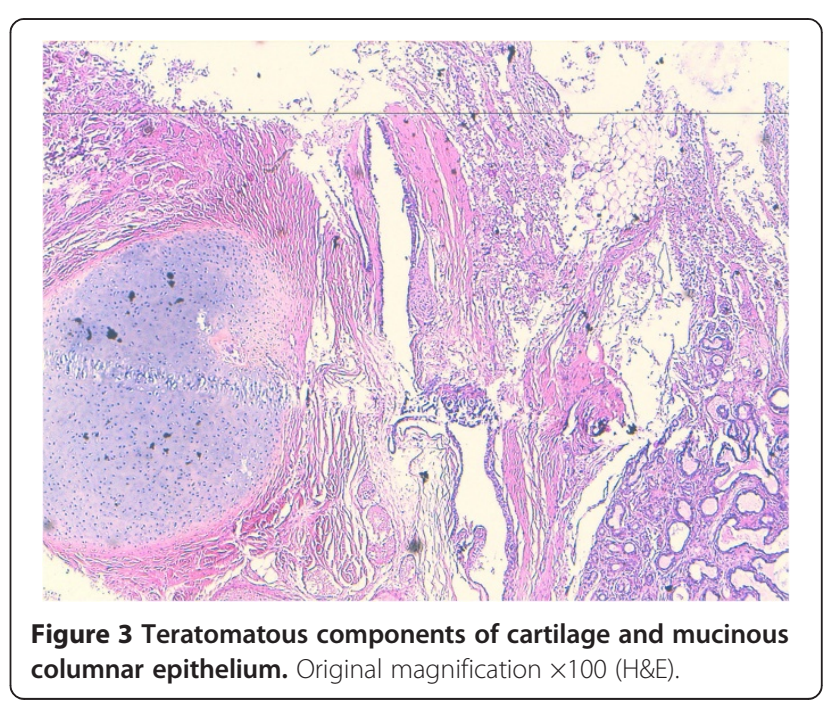




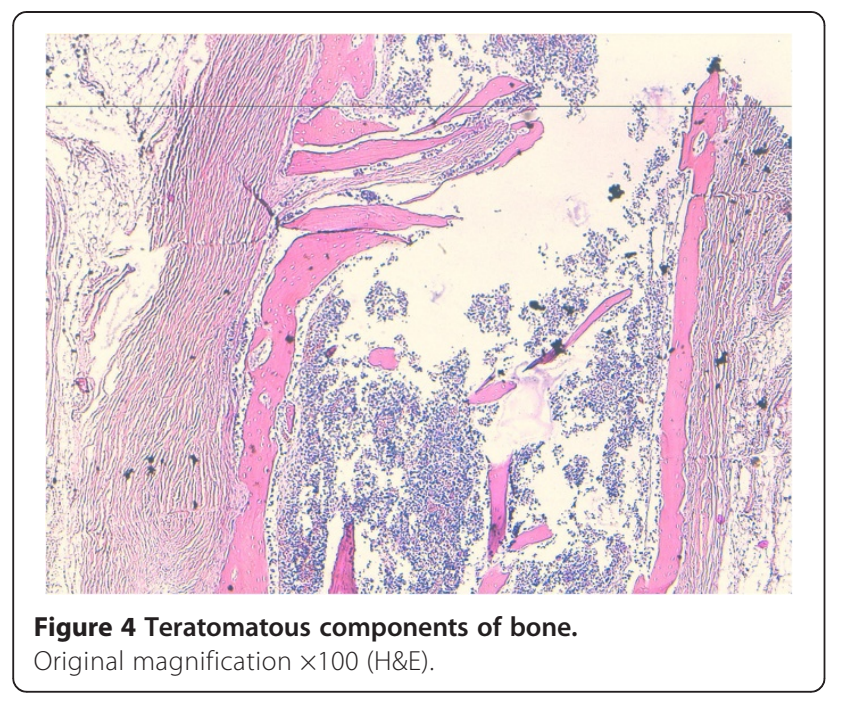

mass, plain X-ray to demonstrate calcification or formed bony components like teeth and phalanges which are pathognomonic. Ultrasound was sufficient to define the relationships of the tumor for planning surgery. CT scan was used to define the extent of the disease in lesions occupying both sides of the retroperitoneum and those tumors where calcification is not seen on plain X-ray. Hayasaka and Yamada have reported internal homogeneity, fat density, cyst formation and calcification to be important predictors of a benign retroperitoneal tumor on CT [4]. The role of magnetic resonance imaging in such tumors is unclear. The single reported case in which magnetic resonance imaging was performed noted a heterogeneous mass with low signal intensity [20]. Papanicolau and Yoder advocate angiography, inferior

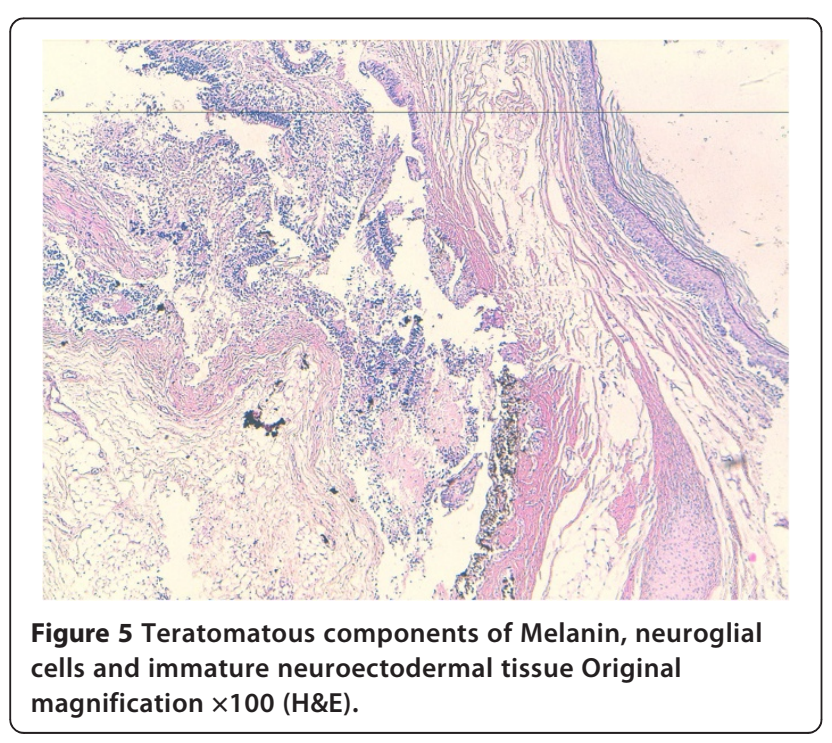

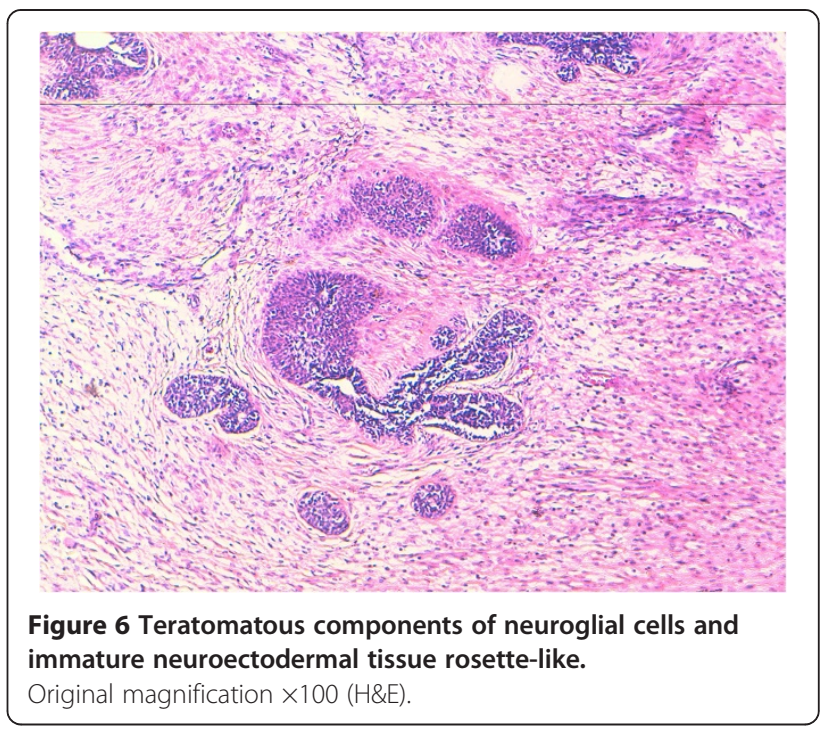

venacavography and needle biopsy for the accurate diagnosis of these tumors. Serum alpha-fetoprotein formed a useful marker of monitoring recurrence [4].

In mature teratomas skin with dermal appendages, bronchial structures with bronchial glands and cartilage, neuroglial tissue, and teeth are commonly present and regarded as evidence of organogenesis. In the other hand immature teratoma contained neuroepithelial components with an embryonic appearance and ependymal rosette-like [10].

Only six cases of primary carcinoid tumor arising in a mature teratoma of the kidney have been reported in the world medical literature to date [19]. Otani et al. reported a case of a six-year-old boy with intrarenal cystic teratoma, associated with renal dysplasia $[1,11]$. M. Mukhopadhyay et al. reported a renal teratoma with duplication of the cecum and appendix. Various congenital anomalies have been reported with renal teratoma [16,20]. Developmental anomalies increase the risk of teratoma $[16,20]$.

The differential diagnosis of intrarenal teratoma include Wilms' tumor [22,23]. The both of these tumors originate from the mesodermal metanephrogenic blastema, and in histological examinations they are similar. Wilms' tumor can contain a variety of heterologous elements with histologic findings of blastemal, stromal, and epithelial cell types $[10,18]$. Therefore, a differential diagnosis between intrarenal teratoma and teratoid nephroblastoma is difficult even when making a pathological diagnosis because it can only be made based on a detailed analysis of the tumor after resection. It is therefore highly possible that anticancer drug treatment is required for Wilms' tumor $[18,20]$.

The second differential diagnosis is congenital mesoblastic nephroma [24]. Sonographically, classic congenital mesoblastic nephroma may appear as a 
Table 1 Clinical-characteristics, radiographic and pathologic features of primary teratoma of the kidney

\begin{tabular}{|c|c|c|c|c|c|c|}
\hline Source, year & Side & Age & Sex & Clinical presentation & Radiographic features of renal mass & Components of teratoma \\
\hline Kojiro et al., [6] & Left kidney & 40 years & Male & $\begin{array}{l}\text { Epigastric pain, nausea, } \\
\text { no carcinoid syndrome }\end{array}$ & $\begin{array}{l}\text { IVU: Marked dilatation of } \\
\text { left renal pelvis }\end{array}$ & $\begin{array}{l}\text { Mucous secretory glands, columnar epithelium, } \\
\text { mature hyaline cartilage, smooth muscle }\end{array}$ \\
\hline Fetissof et al., [7] & Right kidney & 65 years & Male & $\begin{array}{l}\text { Fever, no carcinoid } \\
\text { syndrome }\end{array}$ & $\begin{array}{l}\text { IVU: Displaced left kidney and } \\
\text { non-visualized right kidney }\end{array}$ & $\begin{array}{l}\text { Transitional and mucinous columnar epithelium, } \\
\text { smooth muscle, ossified chondroid plaques, } \\
\text { nerve bundles with ganglion cells }\end{array}$ \\
\hline Lodding et al., [8] & Right kidney & 23 years & Male & $\begin{array}{l}\text { Abdominal pain, } \\
\text { no carcinoid syndrome }\end{array}$ & CT: Calcification in horseshoe kidney & Mature bone \\
\hline LIU et al., [5] & Left kidney & 2 years & Female & $\begin{array}{l}\text { Poor appetite and poor } \\
\text { activity } 1 \text { week in duration }\end{array}$ & $\begin{array}{l}\text { CT: Huge tumor in the left kidney with } \\
\text { calcification and necrosis }\end{array}$ & Yolk sac tumor and immature teratoma \\
\hline Singer et a.l, [9] & Left kidney & 2 months & Male & $\begin{array}{l}\text { Constipation and a } \\
\text { palpable left flank mass }\end{array}$ & $\begin{array}{l}\mathrm{CT} \text { : Heterogeneous upper pole } \\
\text { left renal neoplasm }\end{array}$ & $\begin{array}{l}\text { Mature teratoma with rare } \\
\text { foci of immature elements }\end{array}$ \\
\hline Govender et al., [10] & Right kidney & 3 years & Female & $\begin{array}{l}\text { Bilateral coarse crackles } \\
\text { and a wheeze. } \\
\text { Abdominal distension }\end{array}$ & $\begin{array}{l}\mathrm{CT} \text { : Large tumour involving } \\
\text { The right side of the abdomen }\end{array}$ & $\begin{array}{l}\text { Mature renal teratoma and a synchronous malignant } \\
\text { neuroepithelial tumour of the ipsilateral adrenal gland }\end{array}$ \\
\hline Otani et al., 2001 [11] & Left kidney & 6 years & Male & Mass of a left side abdominal & CT: Multiple cystic masses & $\begin{array}{l}\text { Keratinizing squamous epithelium with hair follicles, } \\
\text { shafts and sebaceous glands. atrophy of the adjacent } \\
\text { renal parenchyma, with partially dysplastic } \\
\text { and angiomyolipoma }\end{array}$ \\
\hline Yoo et al., [12] & Left kidney & 30 years & Female & $\begin{array}{l}\text { Abdominal pain, no } \\
\text { carcinoid syndrome }\end{array}$ & $\begin{array}{l}\text { CT: Dense calcification with minimal } \\
\text { contrast enhancement }\end{array}$ & $\begin{array}{l}\text { Mucinous columnar epithelium, smooth muscle, } \\
\text { mature bone }\end{array}$ \\
\hline Yaqoob et al., [13] & Left kidney & 2 months & Female & $\begin{array}{l}\text { Firm mass on left side of the } \\
\text { abdomen, which was crossing } \\
\text { to the right side as well }\end{array}$ & $\begin{array}{l}\text { X-ray : soft tissue mass with areas of } \\
\text { calcification Ultrasound : complex mass } \\
\text { partly cystic and partly solid }\end{array}$ & $\begin{array}{l}\text { Cystic spaces lined by keratinizing stratified } \\
\text { squamous epithelium with skin adnexae }\end{array}$ \\
\hline Kim et al., [14] & Right kidney & 39 years & Female & $\begin{array}{l}\text { Asymptomatic, incidental renal } \\
\text { mass, no carcinoid syndrome }\end{array}$ & $\begin{array}{l}\text { CT: mass relatively well demarcated and } \\
\text { incompletely marginated by a thin hypodense } \\
\text { rim with globular calcifications }\end{array}$ & $\begin{array}{l}\text { Mucinous columnar and Pseudostratified columnar } \\
\text { epithelium with occasional cilia, mature bone }\end{array}$ \\
\hline Kurzer et al., [15] & Right kidney & 58 years & Female & $\begin{array}{l}\text { Asymptomatic, incidental renal } \\
\text { mass, no carcinoid syndrome }\end{array}$ & $\begin{array}{l}\text { CT: Round mass, smooth, and well marginated, } \\
\text { with two solid clumps of calcifications }\end{array}$ & $\begin{array}{l}\text { Transitional, colonic, squamous, and nonspecific } \\
\text { cuboidal epithelium, mature adipose, } \\
\text { focal osseous metaplasia }\end{array}$ \\
\hline Choi et al., [16] & Right kidney & 4 years & Female & Right-sided abdominal mass & $\begin{array}{l}\text { US : tumor with intermediate echogenicity } \\
\text { and an ovoid, hypoechoic central region }\end{array}$ & $\begin{array}{l}\text { Adipose tissue. squamous epithelial with abundant } \\
\text { keratinous flakes. pilosebaceous adnexal elements }\end{array}$ \\
\hline Ledo et al., [17] & Left kidney & 4 months & Male & Left -sided abdominal mass & $\begin{array}{l}\text { CT: Heterogeneous tumor, amorphous } \\
\text { calcifications }\end{array}$ & Mature teratoma \\
\hline Kyoko et al., [18] & Right kidney & 6 days & Female & $\begin{array}{l}\text { Hard mass of } 6 \times 6 \mathrm{~cm} \text { in } \\
\text { diameter, in the right } \\
\text { upper abdomen }\end{array}$ & $\begin{array}{l}\mathrm{CT} \text { : mass containing low-density areas } \\
\text { from the isthmus to the right lower } \\
\text { pole of a horseshoe kidney }\end{array}$ & $\begin{array}{l}\text { Mature tissu contained neuroepithelial } \\
\text { components }\end{array}$ \\
\hline
\end{tabular}


Table 1 Clinical-characteristics, radiographic and pathologic features of primary teratoma of the kidney (Continued)

\begin{tabular}{|c|c|c|c|c|c|c|}
\hline $\begin{array}{l}\text { Henry B Armah et al., } \\
\text { [19] }\end{array}$ & Right kidney & 35 years & Female & $\begin{array}{l}\text { Right flank pain, right } \\
\text { costovertebral angle } \\
\text { tenderness, no carcinoid } \\
\text { syndrome }\end{array}$ & $\begin{array}{l}\text { CT: Exophytic, round, well-circumscribed mildly } \\
\text { complex hypodense with globular calcifications }\end{array}$ & $\begin{array}{l}\text { Urothelial-type and colonic epithelium, } \\
\text { focal mature bone }\end{array}$ \\
\hline Madhumita et al., [20] & Right kidney & 1 month & Male & $\begin{array}{l}\text { Mass in the right side of } \\
\text { theabdomen since birth }\end{array}$ & $\begin{array}{l}\text { CT: soft tissue density mass with fat and fluid } \\
\text { components arising from the right kidney. } \\
\text { Multiple calcifications duplication of the cecum } \\
\text { and Appendix }\end{array}$ & Mature benign teratoma \\
\hline Current case & Left kidney & 6 months & Female & $\begin{array}{l}\text { Abdominal distension } \\
\text { and pain }\end{array}$ & $\begin{array}{l}\text { US: pelvic left kidney measuring } 18 \mathrm{cms} \text { in } \\
\text { diameter with an important expansion of the } \\
\text { excretory cavities and internal cystic and solid } \\
\text { changes CT: mass containing low-density areas } \\
\text { of the left kidney }\end{array}$ & $\begin{array}{l}\text { keratinizing stratified squamous epithelium with } \\
\text { skin adnexae, cartilage, mucinous columnar } \\
\text { epithelium,bone, melanin containing cells and } \\
\text { neuroglial cells with occasional foci of immature } \\
\text { neuroectodermal tissue }\end{array}$ \\
\hline
\end{tabular}


hypoechogenic tumor with an echogenic rim, but it sometimes may also appear as a heterogenous solid mass like teratoma. A cut section of congenital mesoblastic nephroma reveals an unencapsulated mass having a whorled pattern. As a result, a differential diagnosis between intrarenal teratoma and congenital mesoblastic nephroma may thus be found to be macroscopically possible. Moreover, the histologic features of congenital mesoblastic nephroma mainly consist of elongated spindleshaped cells arranged in interweaving bundles with renal glomeruli and tubules. Classical congenital mesoblastic nephroma has an excellent prognosis in patients younger than the age of 3 months. A radical resection of the tumor is the therapy of choice, and it is usually curative.

Other differential diagnosis is cystic neuroblastomas [25]. This neoplasm is characterized by its cystic appearance with no calcification inside and just a small portion of solid tissue [26].

An immature teratoma has a strong resemblance to small, blue round cell tumors which commonly include Wilm's tumor, metanephric adenoma, lymphoma, peripheral neuroectodermal tumor and rhabdomyosarcoma; and rarely metastatic small cell tumors from lung [23]. It may be present as primary renal cell sarcoma and poorly differentiated renal carcinoma [27].

Beckwith suggests that for a tumor to be termed a renal teratoma it should meet two criteria: (a) the primary tumor should be unequivocally of intrarenal origin, the entire lesion should be contained within the renal capsule and there should be no teratomas in remote sites which might have metastasized to the kidney. (b) the tumor should exhibit unequivocal heterotopic organogenesis [13]. Our case report fulfils both these criteria.

An accurate histologic diagnosis is very important. Complete excision of the tumor mass is recommended and anticancer drug treatment is unnecessary. Patients with pure immature teratomas can be effectively treated with a surgical excision alone because the 3 -year eventfree survival is more than $85 \%$ [18].

Follow-up data after surgical removal for intrarenal teratomas in children are limited. Mature teratomas are usually benign, but they have the potential for malignant transformation. All patients with the diagnosis of benign teratoma should undergo regular long-term follow-up examinations [17].

\section{Conclusion}

The purpose of this review was to stress on the fact that though primary renal teratomas are extremely rare, this entity must be taken into consideration in the differential diagnosis of any renal mass in childhood.

\section{Consent from the patient}

Written informed consent was obtained from patient's parents for publication of this case report.

\section{Abbreviation}

CT: Computed tomography.

\section{Competing interests}

The authors declare that they have no competing interests.

\section{Authors' contributions}

All authors read and approved the final manuscript.

\section{Author details}

${ }^{1}$ Department of Pathology, Hassan II University Hospital, Fez 30000, Morocco.

2Department of Pediatric Surgery, Hassan II University Hospital, Fez 30000,

Morocco.

Received: 3 April 2013 Accepted: 5 June 2013

Published: 25 June 2013

\section{References}

1. Nirmal TJ, Krishnamoorthy S, Korula A: Primary intrarenal teratoma in an adult: A case report and review of literature. Indian J Urol 2009, 25:404-406.

2. Jones NM, Kiely EM: Retroperitoneal teratomas-potential for surgical misadventure. J Pediatr Surg 2008, 43:184-186.

3. Alexander M, Alexander K, Uta B, Holger T, Wolfgang H, Ivo L, Nicole S, Christian W, Thomas A: Mixed hepatoblastoma and teratoma of the liver in a 3-year-old child: a unique combination and clinical challenge. Diagnostic Pathol 2009, 4:37.

4. Amit C, Samir M, Ashish W, Tandon RK, Wakhlu AK: Retroperitoneal Teratomas in Children. Indian J Pediatr 2006, 73:221-223.

5. Liu YC, Wang JS, Chen CJ, Sung PK, Tseng HH: Intrarenal mixed germ cell tumor. J Urol 2000, 164:2020-2021.

6. Kojiro $\mathrm{M}$, Ohishi $\mathrm{H}$, Isobe $\mathrm{H}$ : Carcinoid tumor occurring in cystic teratoma of the kidney: a case report. Cancer 1976, 38:1636-1640.

7. Fetissof F, Benatre A, Dubois MP, Lanson Y, Arbeille-Brassart B, Jobard P: Carcinoid tumor occurring in a teratoid malformation of the kidney an immunohistochemical study. Cancer 1984, 54:2305-2308.

8. Lodding P, Hugosson J, Hansson G: Primary carcinoid tumour with ossification masquerading as calyx stone in a horseshoe kidney. Scand J Urol Nephrol 1997, 31:575-578.

9. Singer AJ, Anders KH: Primary teratoma of the kidney. Urology 2001, 58:1056-1057.

10. Govender D, Nteene LM, Chetty R: Mature renal teratoma and a synchronous malignant neuroepithelial tumor of the ipsilateral adrenal gland. Correspondence J Clin Pathol 2001, 54:253-256.

11. Otani M, Tsujimoto S, Miura M, Nagashima Y: Intrarenal mature cystyc teratoma associated with renal dysplasia: case report and literature review. Pathol Int 2001, 51:560-564.

12. Yoo J, Park S, Jung Lee $H$, Jin Kang S, Kee KB: Primary carcinoid tumor arising in a mature teratoma of the kidney: A case report and review of the literature. Arch Pathol Lab Med 2002, 126:979-981.

13. Yaqoob N, Ahmed Z, Jafri N, Muzaffar S, Hasan SH: Renal Teratoma: a Rare Entity. J Pakistan Med Assoc 2003, 53:10.

14. Kim J, Suh K: Primary carcinoid tumor in a mature teratoma of the kidney: ultrasonographic and computed tomographic findings. J Ultrasound Med 2004, 23:433-437.

15. Kurzer E, Leveillee RJ, Morillo G: Rare case of carcinoid tumor arising within teratoma in kidney. Urology 2005, 66:658.

16. Choi DJ, Wallace EC, Fraire AE: Intrarenal teratoma. Radiographics 2005, 25:481-485.

17. Ledo RMA, Mosquira MCF, Monjoy VMA: Renal teratoma in an infant with an abdominal mass. Rev Mex Pediatr 2006, 73:22-25.

18. Kyoko M, Yasuharu O, Yukiko T, Takashi K, Masahiko O, Akira K, Hiroyuki M, Mitsuru N, Tomayoshi H: Congenital intrarenal teratoma arising from a horseshoe kidney. jpedsurg 2006, 03:019.

19. Henry BA, Parwani AV: Primary carcinoid tumor arising within mature teratoma of the kidney: report of a rare entity and review of the literature. Diagnostic Pathol 2007, 2:15. 
20. Madhumita M, Ram MS, Kartik CM, Biswanath M: Renal teratoma with duplication of cecum and appendix. J ped Surg 2009, 10:053.

21. Auge B, Satge D, Sauvage P: Retroperitoneal teratomas in the perinatal period. Review of literature concerning a neonatal immature aggressive teratoma. Ann Pediatr 1993, 40:613-621.

22. Nirgiotis JG, Black CT, Sherman JO: Wilms' tumor in horseshoe kidney: presentation due to ureteropelvic junction obstruction. J Surg Oncol 1991, 48:210-212.

23. Geethamani V, Kusuma V, Srinivasa KM, Saini M: Adult Wilms' tumour: a case report with review of literature. Diagnostic Pathol 2006, 1:46.

24. Chen WY, Lin CN, Chao CS: Prenatal diagnosis of congenital mesoblastic nephroma in mid-second trimester by sonography and magnetic resonance imaging. Prenat Diagn 2003, 23:927-931.

25. Richards ML, Gundersen AE, Williams MS: Cystic neuroblastoma in infancy. J Pediatr Surg 1995, 30:1354-1357.

26. Tanaka S, Tajiri T, Noguchi S, et al: Prenatally diagnosed cystic neuroblastoma: a report of two cases. Asian J Surg 2003, 26:225-227.

27. Saini M, Krishnamurthy S, Rekha V: Intrapulmonary mature Teratoma. Diagnostic Pathol 2006, 1:38.

doi:10.1186/1746-1596-8-107

Cite this article as: Idrissi-Serhrouchni et al:: Primary renal teratoma: a rare entity. Diagnostic Pathology 2013 8:107.

\section{Submit your next manuscript to BioMed Central and take full advantage of:}

- Convenient online submission

- Thorough peer review

- No space constraints or color figure charges

- Immediate publication on acceptance

- Inclusion in PubMed, CAS, Scopus and Google Scholar

- Research which is freely available for redistribution 